\title{
Bleeding or clotting: an intracranial dilemma
}

\author{
Jonathan Dallimore, ${ }^{1}$ Rahul Bhatnagar ${ }^{2}$
}

${ }^{1}$ Intensive Care Unit, Capital \& Coast District Health Board, Wellington, New Zealand ${ }^{2}$ Academic Respiratory Unit, University of Bristol, Bristol, UK

\section{Correspondence to}

Dr Rahul Bhatnagar, rahul.bhatnagar@bristol.ac.uk

Accepted 9 December 2017

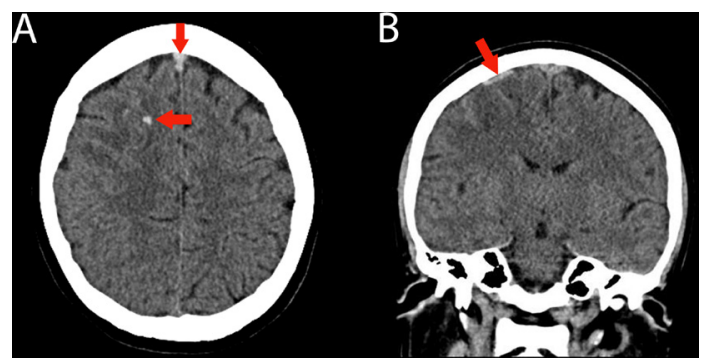

Figure 1 (A) Axial unenhanced CT brain image showing abnormal hyperdense sagittal sinus anteriorly (arrow; compared with the normal low-density portion of the sinus posteriorly) and patchy haemorrhagic change in the right frontal lobe (arrow) with subtle low density in the frontal lobe due to developing oedema/venous infarction related to the venous thrombosis. (B) Coronal unenhanced $\mathrm{CT}$ brain image showing an abnormally dense cortical vein above the right frontal lobe (arrow), in keeping with cortical vein thrombosis (associated with the sagittal sinus thrombosis).

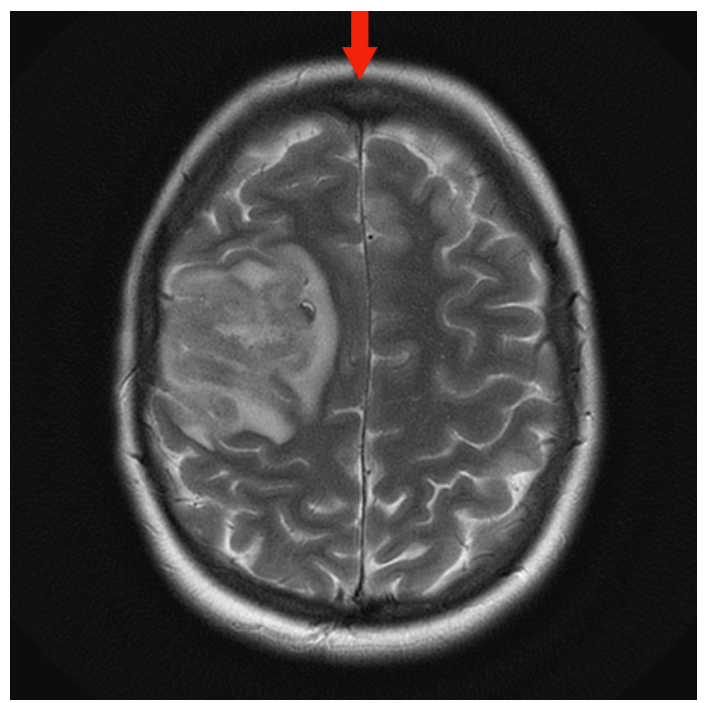

Figure 2 Axial T2 MRI of the brain showing loss of normal flow void in the sagittal sinus anteriorly (arrow) and substantial oedema/swelling in the right frontal lobe with occasional small low-signal parenchymal foci consistent with the known minor patchy haemorrhagic change.
$8 \mathrm{~min}$ seizure in the immediate aftermath. The patient had an acute flare of her UC 2 weeks previously, and her medical history included a deep vein thrombosis following a long-haul flight and a pulmonary embolism while taking contraceptive pill/oral contraceptives.

The patient denied a headache preceding her collapse, although she admitted her head had 'felt fuzzy' during the previous 2 days. CT of the head was performed (figure $1 \mathrm{~A}, \mathrm{~B}$ ), revealing patchy haemorrhagic changes in the right frontal lobe. Abnormal hyperdensity of the superior sagittal sinus and of a cortical vein was also noted; the patient underwent MRI of the head and CT venography, confirming intracranial thrombosis with substantial surrounding oedema (figures 2 and 3). The patient was consequently given a heparin infusion.

Although a head injury can cause intracranial haemorrhage, our patient had multiple risk factors for thrombosis (UC with recent flare, previous deep vein thrombosis and pulmonary embolism) ${ }^{1}{ }^{2}$ which, combined with an unusual pattern of intracranial haemorrhage on CT,

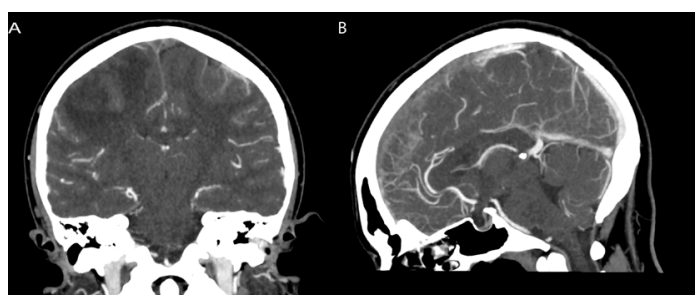

Figure 3 Coronal (A) and sagittal (B) CT venogram of the brain demonstrating the occlusive thrombus in the sagittal venous sinus. A typical 'empty delta sign' is present on the coronal image (A); the sagittal image (B) shows a patent posterior portion of the sagittal sinus with occluded sinus more anteriorly.

\section{Learning points}

- Ulcerative colitis is an independent risk factor for venous thrombosis with a lifetime incidence of around 6\%.

- Venous infarction secondary to cerebral venous thrombosis appears as intracranial haemorrhage on imaging in $30 \%-40 \%$ of cerebral venous thrombosis.

- Plain CT head images provide a diagnosis of cerebral venous thrombosis in approximately $30 \%$ of cases; in the event of a normal CT head, diagnostic suspicion must guide appropriate further imaging such as CT/magnetic resonance venography. 
triggered consideration of the alternative diagnosis of intracranial thrombosis, in which associated haemorrhage is a feature in $30 \%-40 \%$ of cases.

Contributors JD drafted the case and revised it critically for important intellectual content. RB reviewed the drafted manuscript, revised it critically for important intellectual content and obtained patient consent.

Competing interests None declared.

Patient consent Obtained.
Provenance and peer review Not commissioned; externally peer reviewed.

(C) BMJ Publishing Group Ltd (unless otherwise stated in the text of the article) 2018. All rights reserved. No commercial use is permitted unless otherwise expressly granted.

\section{REFERENCES}

1 Miehsler W, Reinisch W, Valic E, et al. Is inflammatory bowel disease an independent and disease specific risk factor for thromboembolism? Gut 2004;53:542-8.

2 Wasay M, Bakshi R, Bobustuc G, et al. Cerebral venous thrombosis: analysis of a multicenter cohort from the United States. I Stroke Cerebrovasc Dis 2008;17:49-54.

Copyright 2018 BMJ Publishing Group. All rights reserved. For permission to reuse any of this content visit http://group.bmj.com/group/rights-licensing/permissions.

BMJ Case Report Fellows may re-use this article for personal use and teaching without any further permission.

Become a Fellow of BMJ Case Reports today and you can:

- Submit as many cases as you like

- Enjoy fast sympathetic peer review and rapid publication of accepted articles

- Access all the published articles

- Re-use any of the published material for personal use and teaching without further permission

For information on Institutional Fellowships contact consortiasales@bmjgroup.com

Visit casereports.bmj.com for more articles like this and to become a Fellow 